\title{
Ultrasoft Ground Treatment of Vacuum Preloading Combined with Calcium-Based Flocculants
}

\author{
Jin-Kai Yan $\left(\mathbb{D},{ }^{1}\right.$ Feng Ji, ${ }^{2}$ Xia Bian $\left(\mathbb{D},{ }^{3,4}\right.$ Gui-Zhong Xu, ${ }^{5}$ Lei Liu, ${ }^{6}$ Xue-Ling Liu, ${ }^{7}$ \\ and Jian-Hua Song ${ }^{8}$ \\ ${ }^{1}$ Chinese Academy of Geological Sciences, Beijing 100037, China \\ ${ }^{2}$ Jiangsu Water Source Company Ltd. of the Eastern Route of the South-to-North Water Diversion Project, Nanjing 210000, China \\ ${ }^{3}$ Institute for Underground Space and Geoenvironment, School of Earth Sciences and Engineering, Nanjing University, \\ Nanjing 210046, China \\ ${ }^{4}$ Key Laboratory of Ministry of Education for Geomechanics and Embankment Engineering, Hohai University, \\ Nanjing 210098, China \\ ${ }^{5}$ Geotechnical Research Institute, Yancheng Institute of Technology, Yancheng 224005, China \\ ${ }^{6}$ Beijing City University, Beijing 10083, China \\ ${ }^{7}$ School of Geological Engineering and Geomatics, Chang'an University, Xi'an 710054, China \\ ${ }^{8}$ Institute of Geology and Mineral Resources of Shandong Province, Jinan 250109, China
}

Correspondence should be addressed to Xia Bian; bianxia2010@gmail.com

Received 10 November 2020; Revised 17 December 2020; Accepted 18 December 2020; Published 29 December 2020

Academic Editor: Chong Xu

Copyright (c) 2020 Jin-Kai Yan et al. This is an open access article distributed under the Creative Commons Attribution License, which permits unrestricted use, distribution, and reproduction in any medium, provided the original work is properly cited.

Vacuum preloading is one of the popular methods improving the engineering properties of slurry ground with high water content. Commonly, the efficiency of vacuum preloading gradually decreased due to the clogging of prefabricated vertical drains (PVDs) and the low-vacuum transmission rate inside slurry. Thus, the calcium-based flocculants were used to accelerate the dewater capacity and enhance the soil strength during vacuum preloading. This paper performed a series of model tests to investigate the effect of calcium-based flocculants on the efficiency of vacuum preloading. It is found that the vacuum transmission rate was significantly improved by flocculants in comparison with raw slurry. Accordingly, the after-treatment undrained shear strength increased with the vacuum pressure, while the after-treatment water showed a decrease trend. This suggests that the increase of vacuum transmission rate inside the slurry due to the calcium-based flocculants was the main reason for the improvement of efficiency of vacuum preloading. In addition, there existed an optimal flocculants amount, where the vacuum pressure increased with flocculants' amount up to this threshold value, followed by a decrease in vacuum pressure. This means that, at lower flocculants amount, the increase in soil flocs due to flocculation effect tended to refine the net-frame structure and water flow path, leading to an increase in the efficiency of vacuum preloading. When exceeding the optimal amount, overdosage of flocculants resulted in the clogging of PVDs due to large cemented soil particles, reducing the vacuum transmission rate inside the slurry. Hence, the after-treatment soil strength decreased with flocculants' amount when it is higher than the optimal value.

\section{Introduction}

Every year, tons of thousands of dredged soils with high initial water content are dredged from the rivers and lakes over the world. Specifically, over 100 million $\mathrm{m}^{3}$ of dredged soil were generated from the two major river regions (Yangtze River and Yellow River) in China annually [1-4]. These dredged soils were often stored inside a mud pond, regarded as waste materials, or used as fill materials in land reclamation projects $[5,6]$. However, these dredged soils possessed poor engineering properties, such as high water content and low strength, leading to the low bearing capacity in terms of ground foundation. Hence, additional ground improvement techniques should be implemented to enhance the soil strength properties and to shorten the consolidation period. 
In general, vacuum preloading is one of the favourite methods to improve the engineering characteristic of slurry foundation, especially suitable for the large area ground improvement due to its simple and fast construction operation, as well as the low cost [7-11]. In this technique, prefabricated vertical drains (PVDs) were implemented inside the slurry as the water flow channel. Meantime, vacuum pressure was transmitted into the slurry through PVDs. However, there were two main common problems related to this method: (1) the clogging effect of PVDs due to the fine-grained particles which led to the decrease in vacuum pressure transmission and (2) the low transmission rate of vacuum pressure due to the low permeability of slurry. This behaviour would lower the treatment efficiency of vacuum preloading, resulting in the decrease in the aftertreatment soil strength, as well as the reduction in the extent of treatment scope [12-16].

To deal with these disadvantages, chemical additives, especially flocculants and others, were recently added to improve the efficiency of vacuum preloading $[17,18]$. By introducing the flocculants into slurry, the large soil particles with the formation of a flocs net-frame structure was formed due to the flocculation effect [19]. Thus, the dewater capacity of slurry with flocculants increased with an increase in soil permeability and settlement rate. Hence, combining with the vacuum preloading method will significantly improve the effectiveness of vacuum consolidation [6]. Commonly, the flocculants such as $\mathrm{FeCl}_{3}$ or $\mathrm{CaO}$ were used as the chemical additives combined with vacuum preloading method. It is clear that the cation exchange between flocculants and the soil particles brought out the formation of flocculated fabric, leading to the increase in soil strength. This was beneficial to the particle movement during vacuum preloading, which eventually reduced the clogging effect of PVDs. Moreover, polyacrylamide (PAM) was often combined with the calciumbased flocculants (i.e., $\mathrm{CaO}$ ) to produce calcium ion bridging the PAM and soil particles and increase the bonding strength between PAM and soil particles. This would further enhance the soil strength as well as the efficiency of vacuum consolidation [20-22].

Although previous studies showed that the chemical flocculants improved the efficiency of vacuum preloading, two questions still need to be addressed: (1) how do the flocculants influence the vacuum pressure transmission inside slurry? This may be the primary factor controlling the effectiveness of vacuum preloading method. (2) To what extent of flocculants amount did the efficiency of vacuum preloading increase? With these questions in mind, a series of vacuum preloading model tests with two calcium-based flocculants $\left(\mathrm{Ca}(\mathrm{OH})_{2}\right.$ and $\left.\mathrm{CaCl}_{2}\right)$ were conducted to improve the efficiency of vacuum preloading. Firstly, the effect of flocculants on vacuum transmission rate was first discussed to evaluate the efficiency of vacuum transmission inside the slurry. Then, the variation of soil settlement and extracted water amount, as well as after-treatment soil strength and water content with flocculants amounts, was studied in terms of the relationship with vacuum pressure. Finally, the effect of flocculants on the efficiency of vacuum preloading was discussed, correlating with the changes in vacuum transmission rate.

\section{Materials and Methods}

2.1. Materials. The dredged soil used in this study was obtained from a mud pond in Bengbu city, Anhui province, China. The basic physical properties of the Bengbu soil are summarised in Table 1. Bengbu soil was classified as highplasticity clay $(\mathrm{CH})$ based on the Unified Soil Classification System [23]. The initial water content of dredged soil in the mud pond was $116 \%$.

Two calcium-based additives were used in this study as the flocculants, calcium chloride $\left(\mathrm{CaCl}_{2}\right)$ and calcium hydroxide $\left(\mathrm{Ca}(\mathrm{OH})_{2}\right)$, which were commonly used to accelerate the soil sediment rate. These two types of flocculants used in this study were manufactured by Damao Chemical Reagent Factory, Tianjin, China. These chemical additives were obtained as white powder. Table 2 presents the basic compositions of the two flocculants. Note that the purity of these flocculants was higher than 95.0\%. Meanwhile, the impurity content was at very low level, less than $1 \%$.

2.2. Experimental Methods. The experimental test setup is presented in Figure 1. The slurry tank was $300 \mathrm{~mm}$ in diameter and $500 \mathrm{~mm}$ in height. During the test, the dredged soil was poured into the tank, with the slurry height of $450 \mathrm{~mm}$. Then, the sealing membrane was used to cover and seal the top boundary of slurry. The prefabricated vertical drain (PVD) wrapped with the woven geotextile was inserted inside the slurry. The diameter of PVD was about $20 \mathrm{~mm}$. The PVD vertical drain was connected to the vacuum pump at the top. The vacuum gauges were installed at the top and bottom of the PVD, monitoring the variation of vacuum degree during the test. To evaluate the vacuum transmission inside the slurry, three vacuum probes were placed in the slurry, at depth of $120 \mathrm{~mm}$ from bottom, with the distance to PVD of $2 \mathrm{~cm}, 6 \mathrm{~cm}$, and $12 \mathrm{~cm}$, respectively. Meanwhile, a dial gauge was placed on the top of slurry to measure the slurry settlement during the test.

To evaluate the effect of flocculants on the vacuum consolidation characteristic, 11 experiment tests were conducted, with five calcium chloride contents $(0.1 \%, 0.3 \%, 0.5 \%$, $1 \%$, and $2 \%)$ and five calcium hydroxide contents $(0.1 \%, 0.3 \%$, $0.5 \%, 1 \%$, and $2 \%$ ), as well as one test with raw slurry for comparison purpose. Before the test, the slurry with initial water content of $116 \%$ was mixed with a predetermined amount of calcium chloride or calcium hydroxide to a homogeneous paste and then transformed into the tank. The initial density of slurry was about $1.54 \mathrm{~g} / \mathrm{cm}^{3}$ for all tests. The detailed test programme is presented in Table 3.

During the test, the vacuum pump was continuously operated for about 20 days, which can apply a maximum vacuum degree of higher than $-90 \mathrm{kPa}$ inside the PVD. The extracted water amount was recorded manually by measuring the weight change of water-air separation bottle.

After the test, the soil sample at different position (close to the vacuum probes) was extracted from the tank. Then, the samples were carefully cut into small pieces for the determination of water content and undrained shear 
TABLE 1: Basic physical properties of Bengbu clays.

\begin{tabular}{lcccccc}
\hline Soils & $\begin{array}{c}\text { Density of soil particles } \\
\left(\mathrm{Mg} / \mathrm{m}^{3}\right)\end{array}$ & $\begin{array}{c}\text { Liquid limit } \\
(\%)\end{array}$ & $\begin{array}{c}\text { Plastic limit } \\
(\%)\end{array}$ & $\begin{array}{c}\text { Clay }(<0.005 \mathrm{~mm}) \\
(\%)\end{array}$ & $\begin{array}{c}\text { Silt }(0.005-0.075 \mathrm{~mm}) \\
(\%)\end{array}$ & $\begin{array}{c}\text { Sand }(0.075 \sim 2 \mathrm{~mm}) \\
(\%)\end{array}$ \\
\hline $\begin{array}{l}\text { Bengbu } \\
\text { clay }\end{array}$ & 2.70 & 58.3 & 26.3 & 55 & 44 & 1 \\
\hline
\end{tabular}

TABLE 2: Basic properties of flocculants.

\begin{tabular}{lccccc}
\hline Flocculants & Molecular weight & Purity (\%) & Impurity content (\%) & Insoluble matter content (\%) & Heavy metal content (\%) \\
\hline $\mathrm{CaCl}_{2}$ & 110.99 & $\geq 96$ & $\leq 0.5$ & $\leq 0.015$ & $\leq 0.5$ \\
$\mathrm{Ca}(\mathrm{OH})_{2}$ & 74.09 & $\geq 95$ & $\leq 1.0$ & $\leq 0.25$ & $\leq 0.002$
\end{tabular}

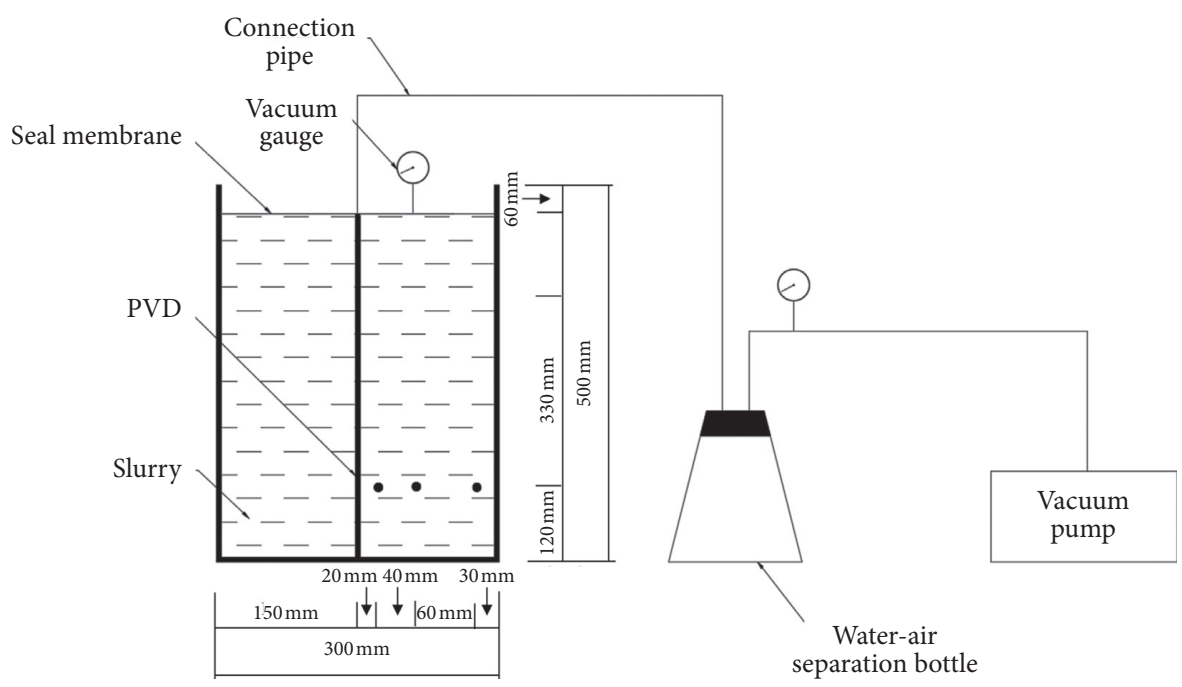

- Vacuum probe

FIgURE 1: Schematic of vacuum consolidation device.

TABle 3: Programme of vacuum preloading test.

\begin{tabular}{|c|c|c|c|c|}
\hline Chemical additive & Slurry initial water content (\%) & Amount of chemical additive (\%) & Slurry weight $(\mathrm{kg})$ & Initial density (\%) \\
\hline \multirow{6}{*}{$\mathrm{Ca}(\mathrm{OH})_{2}$} & \multirow{6}{*}{116} & 0.0 & 54 & 1.54 \\
\hline & & 0.1 & 54 & 1.54 \\
\hline & & 0.3 & 54 & 1.54 \\
\hline & & 0.5 & 54 & 1.54 \\
\hline & & 1.0 & 54 & 1.54 \\
\hline & & 2.0 & 54 & 1.54 \\
\hline \multirow{6}{*}{$\mathrm{CaCl}_{2}$} & \multirow{6}{*}{116} & 0.0 & 54 & 1.54 \\
\hline & & 0.1 & 54 & 1.54 \\
\hline & & 0.3 & 54 & 1.54 \\
\hline & & 0.5 & 54 & 1.54 \\
\hline & & 1.0 & 54 & 1.54 \\
\hline & & 2.0 & 54 & 1.54 \\
\hline
\end{tabular}

strength. The water content was determined by oven-drying the sample at $105^{\circ} \mathrm{C}$ for 24 hours [24-26].

\section{Results}

3.1. Vacuum Degree. Figures 2 and 3 show the variation of vacuum degree at the top and bottom of slurry treated with calcium chloride $\left(\mathrm{CaCl}_{2}\right)$ and calcium hydroxide $\left(\mathrm{Ca}(\mathrm{OH})_{2}\right)$, respectively. Note that the vacuum load generated by the vacuum pump was up to $-98 \mathrm{kPa}$. The graphs showed that the vacuum degree kept almost constant during the test. It is clear that the vacuum degree curve with the calcium-based flocculants (calcium chloride or calcium hydroxide) was higher than that without flocculants in raw slurry at both the top and bottom of slurry. This suggested that the presence of flocculants can increase the transmission of vacuum pressure inside the slurry, which would improve the vacuum treatment efficiency. 


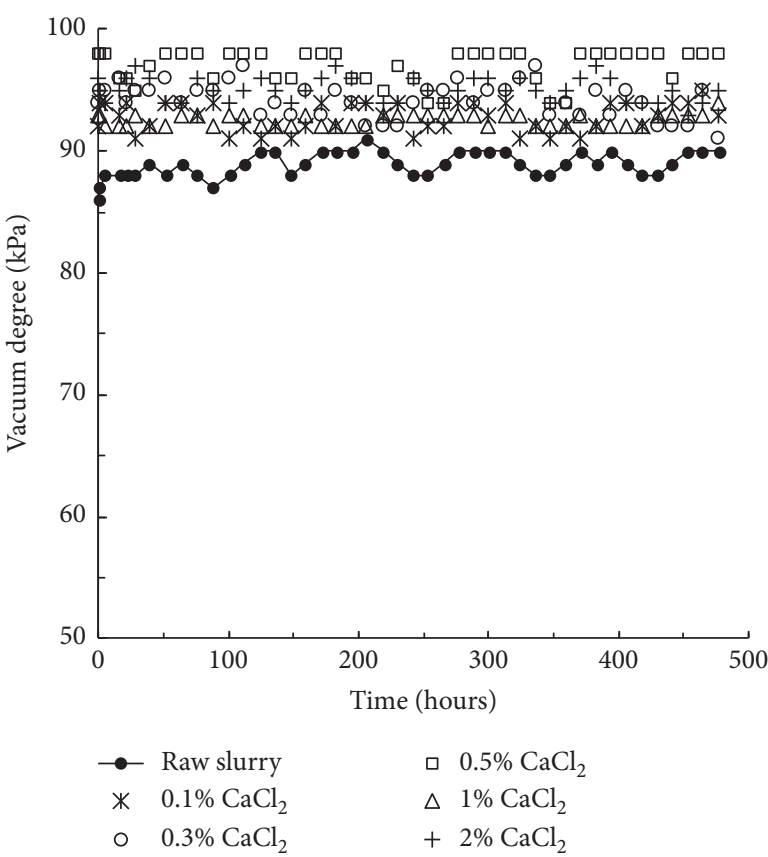

(a)

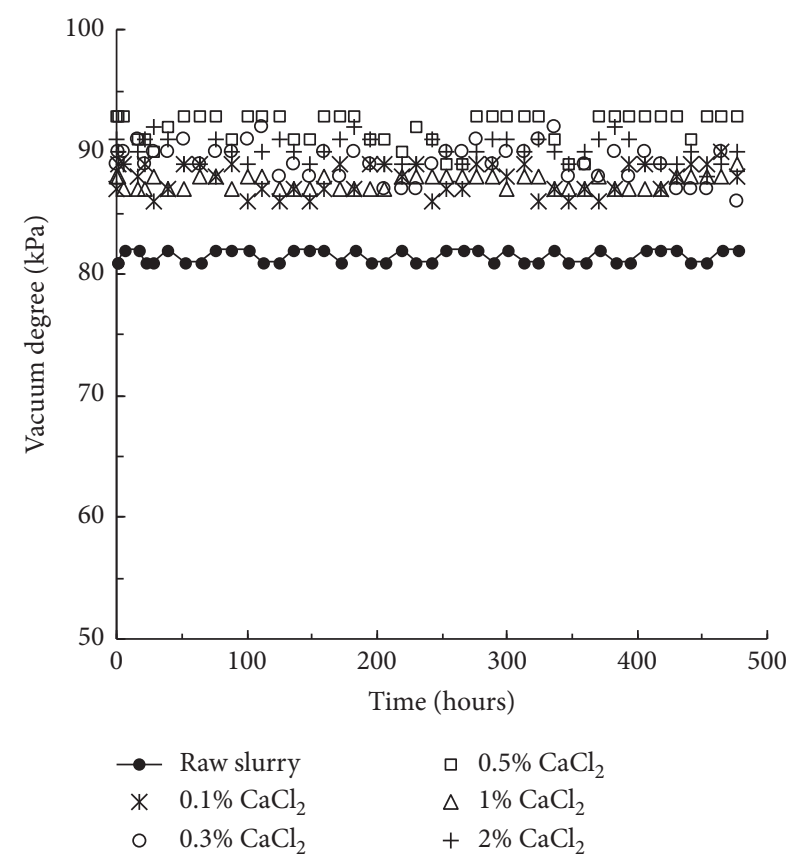

(b)

Figure 2: Vacuum degree versus time. (a) Top. (b) Bottom.

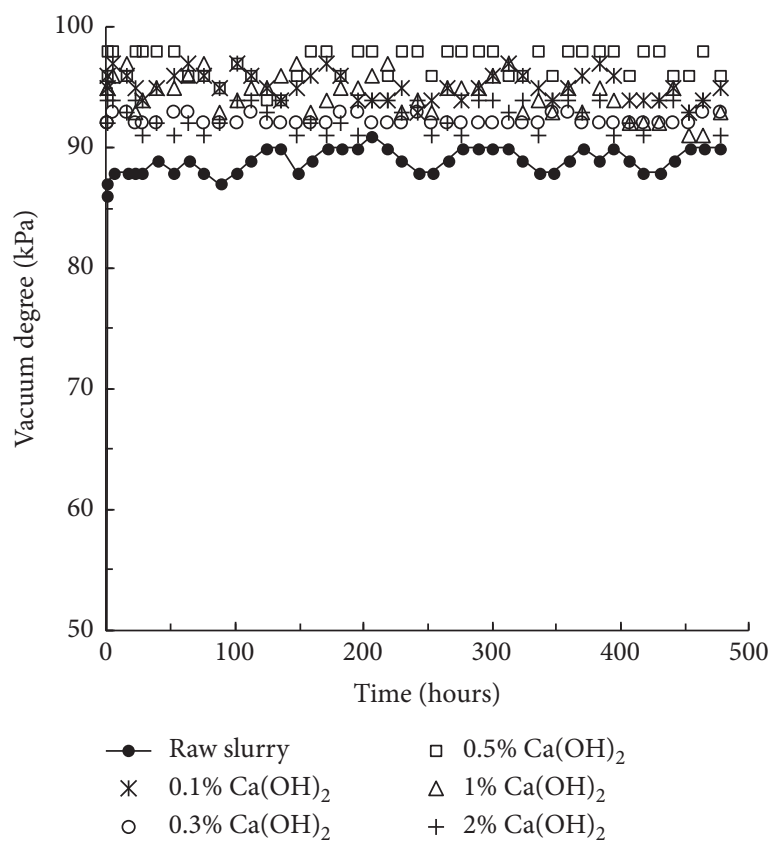

(a)

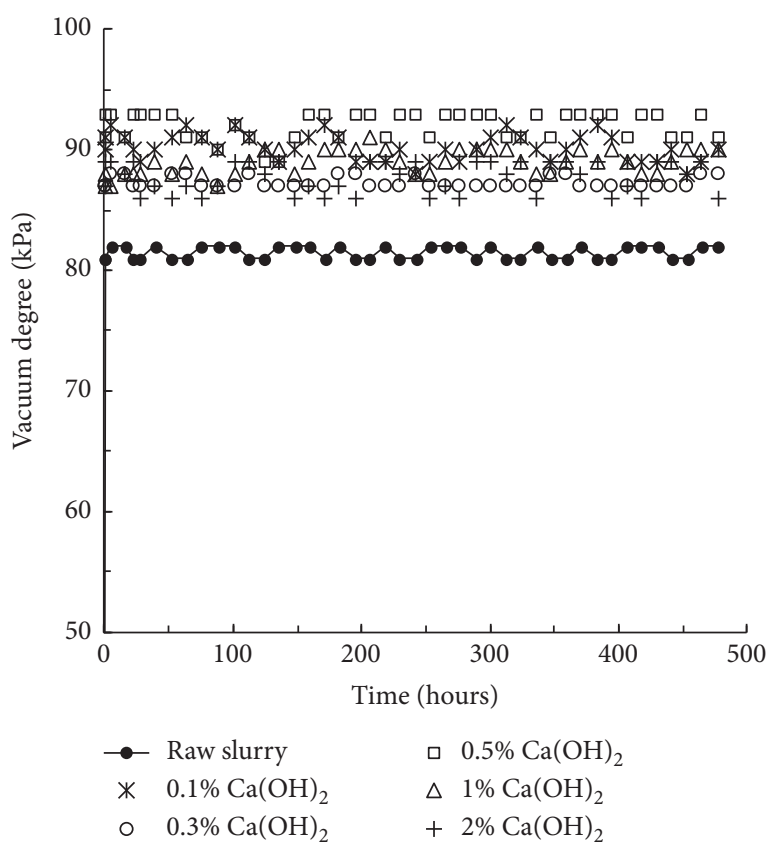

(b)

Figure 3: Vacuum degree versus time. (a) Top. (b) Bottom.

The variation of average vacuum degree with flocculants amount was plotted in Figure 4. The applied vacuum pressure at the top and bottom of slurry increased when the $\mathrm{CaCl}_{2}$ amount increased from $0 \%$ to $2 \%$. For the case of $\mathrm{Ca}(\mathrm{OH})_{2}$, it appeared that the applied vacuum pressure increased the $\mathrm{Ca}(\mathrm{OH})_{2}$ amount up to $0.5 \%$ and then slightly decreased with further increase in $\mathrm{Ca}(\mathrm{OH})_{2}$ amount. Hence, it can be deduced that there was an optimal flocculants' amount that provided the highest vacuum pressure. For the Bengbu slurry with initial water content of $116 \%$, the optimal content of $\mathrm{Ca}(\mathrm{OH})_{2}$ was $0.5 \%$. However, the optimal content of $\mathrm{CaCl}_{2}$ may be higher than $2 \%$, beyond the experimental design in this study.

Moreover, there was a clear difference in the vacuum pressure between the top and bottom of slurry. This 


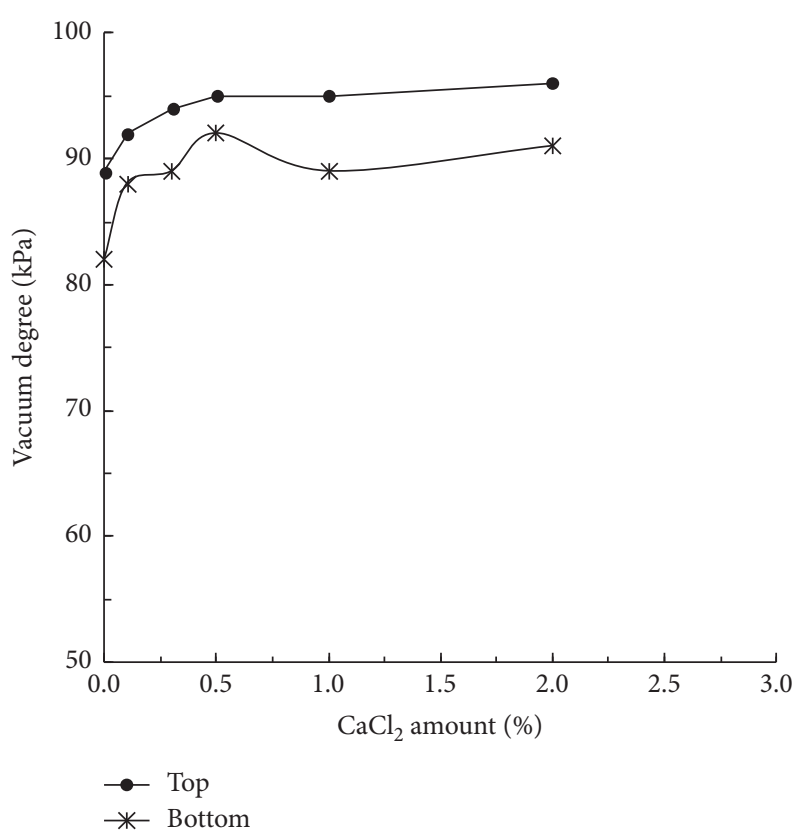

(a)

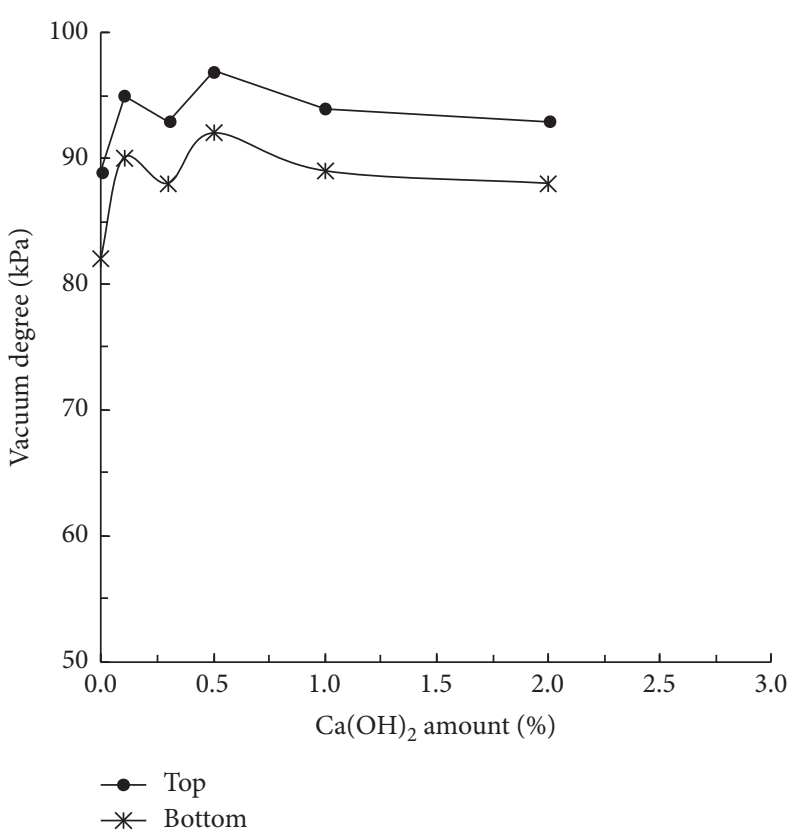

(b)

FIgURE 4: Variation of average vacuum degree.

difference corresponded to the loss of vacuum degree along the vertical drains $[27,28]$. The loss of vacuum pressure for raw slurry was $7 \mathrm{kPa}$, while the average loss of vacuum pressure for soil with flocculants was about $5 \mathrm{kPa}$. A slight improvement in vacuum loss was also observed.

3.2. Vacuum Transmission inside Slurry. Figure 5 presents the variation of vacuum degree with distance to PVD for slurry with $\mathrm{CaCl}_{2}$. At $h=2 \mathrm{~cm}$, the variation of vacuum degree can be divided into three stages: (1) no vacuum degree was recorded, corresponding to the time of vacuum transmission from PVD to the target distance, (2) the vacuum degree increased with time, and (3) a stable vacuum degree remained unchanged with time. It can be observed that the time of vacuum recorded by vacuum probe at $h=2 \mathrm{~cm}$ remarkably decreased for the slurry treated with $\mathrm{CaCl}_{2}$, indicating that the vacuum transmission rate in slurry with $\mathrm{CaCl}_{2}$ was higher than that without $\mathrm{CaCl}_{2}$. This was also observed in stage 2, where the slope of vacuum degree versus time increased with $\mathrm{CaCl}_{2}$ amount. Finally, the stable vacuum degree showed a clear increase tendency with $\mathrm{CaCl}_{2}$ amount. Similar trends were observed in Figures 5(b) and 5(c) for $h=6$ and $12 \mathrm{~cm}$, respectively.

For the case of slurry with $\mathrm{Ca}(\mathrm{OH})_{2}$ as shown in Figure 6, the general trend of vacuum transmission with time was similar to the observation in Figure 5. However, the change in time of vacuum recorded, the slope of vacuum degree versus time in stage 2 , and stable vacuum degree did not monotonously increase with $\mathrm{Ca}(\mathrm{OH})_{2}$ amount. It can be observed that the time of vacuum recorded for slurry with $0.5 \% \mathrm{Ca}(\mathrm{OH})_{2}$ was significantly less than the rest of $\mathrm{Ca}(\mathrm{OH})_{2}$ amount. This suggested that the vacuum transmission rate for slurry with $0.5 \% \mathrm{Ca}(\mathrm{OH})_{2}$ was the highest. Meanwhile, the slurry with $0.5 \% \mathrm{Ca}(\mathrm{OH})_{2}$ also possessed the highest slope of vacuum degree versus time and stable vacuum degree.

Figure 7 depicts the variation of stable vacuum degree flocculants amount. Note that $h=0 \mathrm{~cm}$ represented the vacuum degree in PVD at depth of $12 \mathrm{~cm}$ from the bottom, which was deduced from the change in vacuum degree at the top and bottom of slurry (Figures 2 and 3). There was a significant reduction between the vacuum degree in PVD and the slurry. This means that the water extracted from slurry consumed the applied energy from vacuum pump, resulting in the decrease in vacuum degree with the increase in distance to PVD.

It should be emphasized that the stable vacuum degree at different distance to PVD increased with $\mathrm{CaCl}_{2}$ amount, while the stable vacuum degree increased with the $\mathrm{Ca}(\mathrm{OH})_{2}$ amount up to $0.5 \%$ and followed by a decrease tendency. This behaviour was consistent with the variation of vacuum degree at the top and bottom of slurry in PVD. Hence, the vacuum transmission characteristics imply that the slurry with calcium-based flocculants was able to significantly improve the vacuum transmission rate in slurry, leading to a higher stable vacuum degree inside the slurry than that without flocculants, whereas there was an optimal flocculants' amount to produce the highest vacuum degree inside the slurry.

3.3. Settlement. Figure 8 shows the evolution of consolidation settlement during the test. Due to the continuous vacuum loading condition applied to the slurry, the evolution of settlement subjected to a rapid linear increase stage at the beginning, then tended to a slow increase rate, and finally reached a final settlement, remaining unchanged with time. 


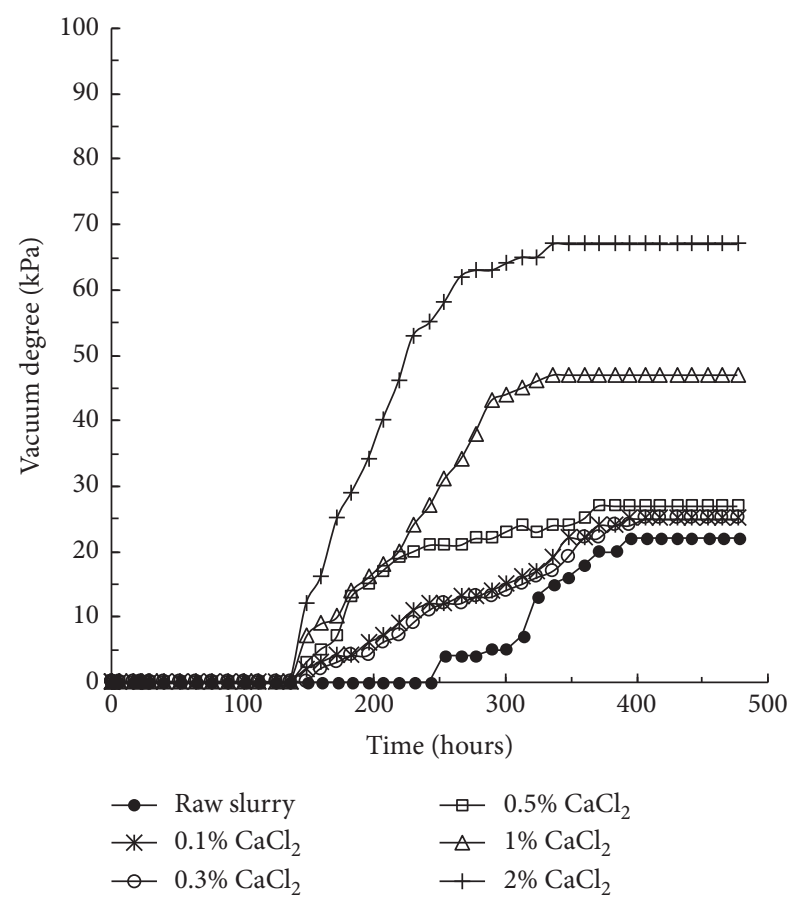

(a)

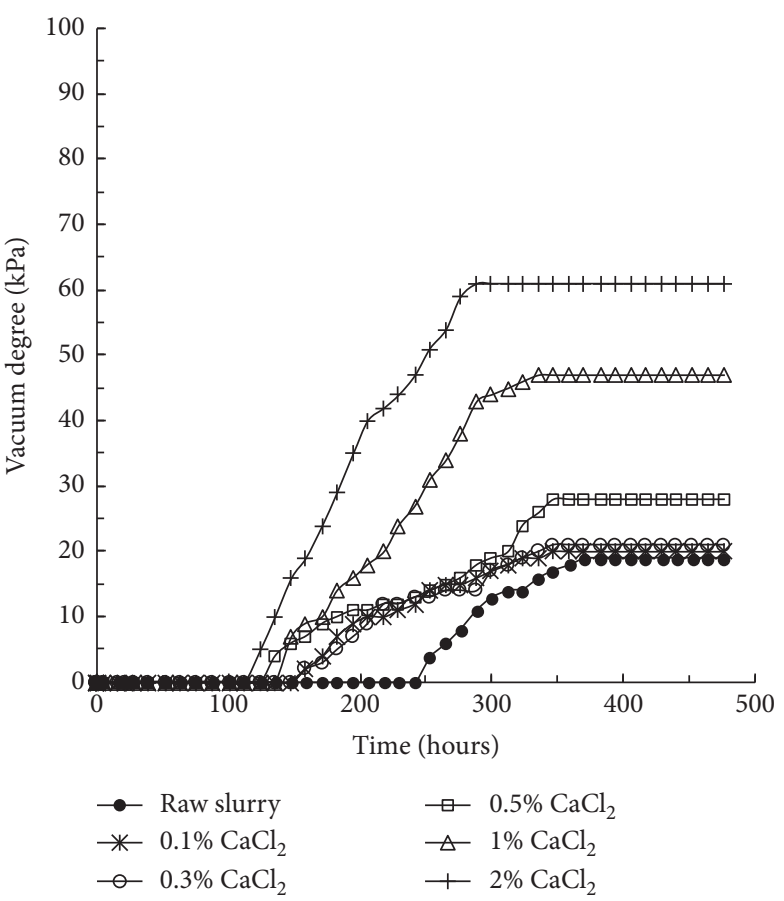

(b)

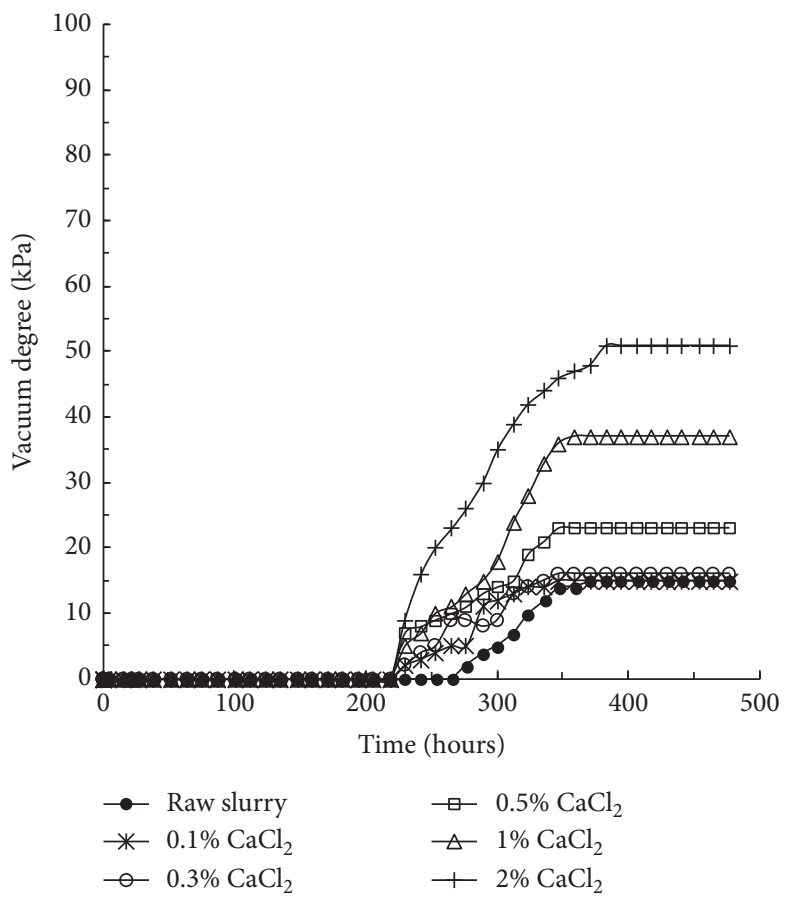

(c)

FIgURE 5: Variation of vacuum degree with distance to PVD for slurry with $\mathrm{CaCl}_{2}$. (a) $h=2 \mathrm{~cm}$. (b) $h=6 \mathrm{~cm}$. (c) $h=12 \mathrm{~cm}$.

For the slurry with $\mathrm{CaCl}_{2}$, it can be observed that the higher the $\mathrm{CaCl}_{2}$ amount was, the faster the settlement rate obtained at the beginning was. This behaviour means the acceleration of consolidation process shortened the required time period to achieve the given settlement in comparison with the raw slurry. As expected, the final settlement increased with the increase in $\mathrm{CaCl}_{2}$ amount.
On the other hand, a rapid increase of settlement rate at the beginning was also observed when $\mathrm{Ca}(\mathrm{OH})_{2}$ was used as the flocculants as shown in Figure 8(b). However, a threshold of $\mathrm{Ca}(\mathrm{OH})_{2}$ amount at $0.5 \%$ was observed, with an increase in the settlement rate when the $\mathrm{Ca}(\mathrm{OH})_{2}$ amount was lower than $0.5 \%$ and a decrease in the settlement rate while the $\mathrm{Ca}(\mathrm{OH})_{2}$ amount exceeded $0.5 \%$. Accordingly, the 


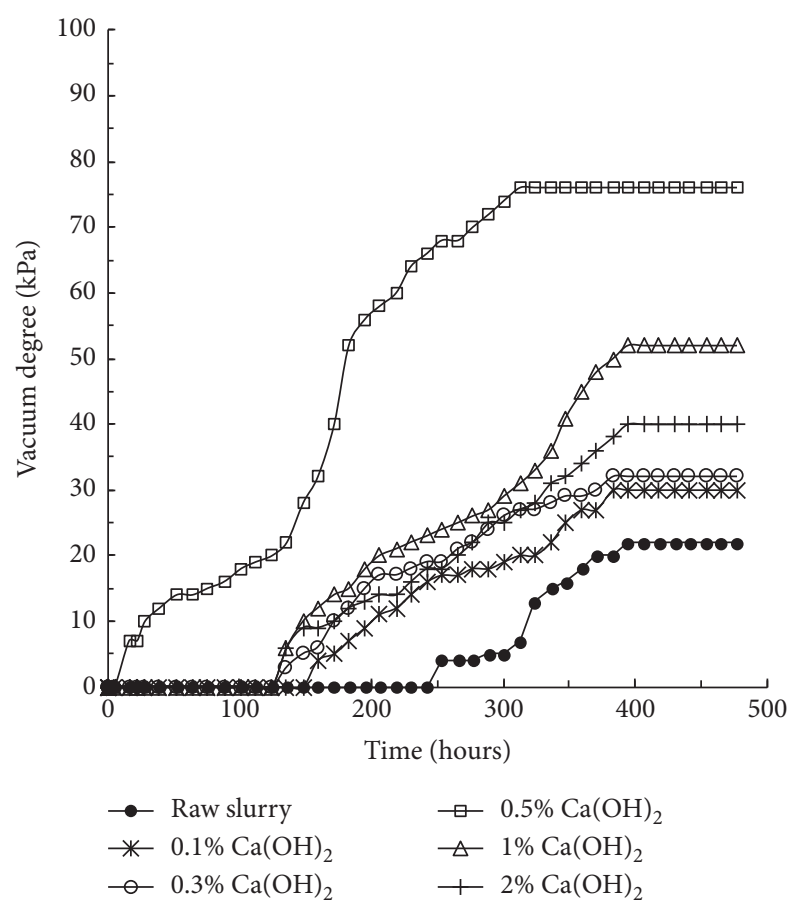

(a)

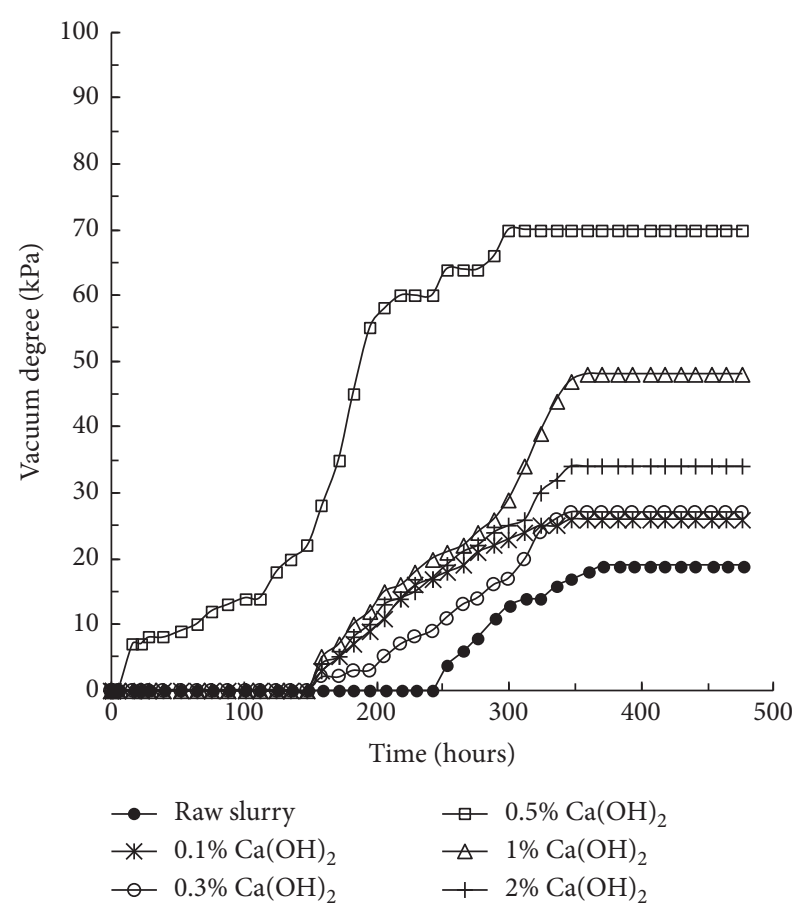

(b)

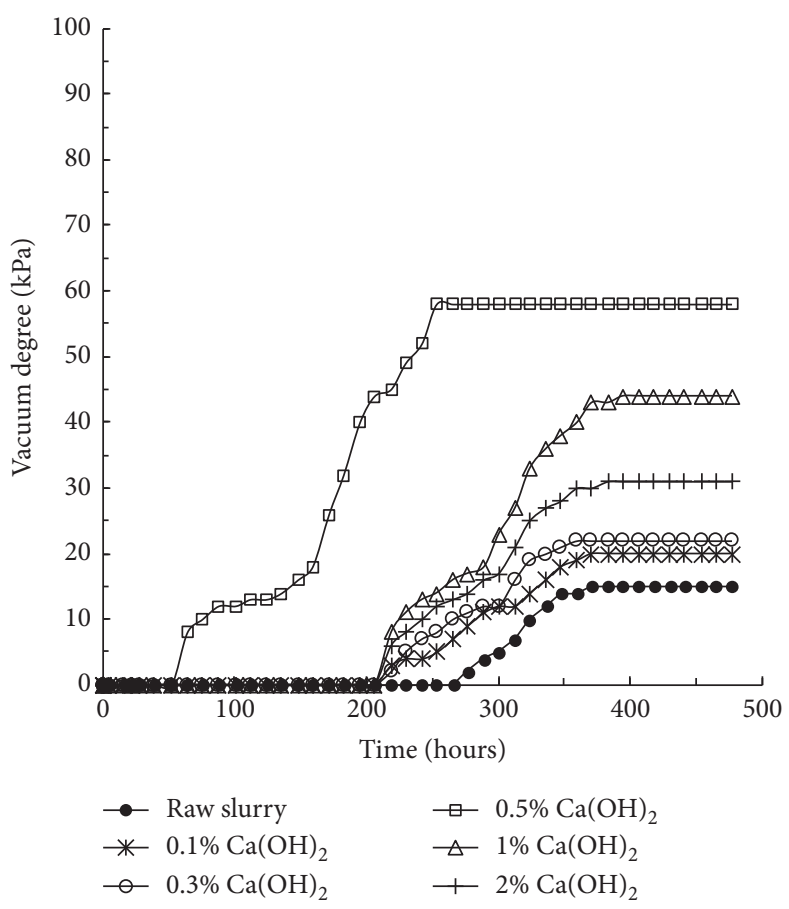

(c)

FIgUre 6: Variation of vacuum degree with distance to PVD for slurry with $\mathrm{Ca}(\mathrm{OH})_{2}$. (a) $h=2 \mathrm{~cm}$. (b) $h=6 \mathrm{~cm}$. (c) $h=12 \mathrm{~cm}$.

final settlement increased with the $\mathrm{Ca}(\mathrm{OH})_{2}$ amount up to $0.5 \%$ till reaching the peak value, followed by a decrease in the final settlement with further increase in the $\mathrm{Ca}(\mathrm{OH})_{2}$ amount.

As previously mentioned, the vacuum pressure was continuously implemented into the slurry. Hence, the slurry settlement correlated to the average vacuum pressure applied inside the slurry. Figure 9 illustrates the variation of average vacuum pressure inside slurry with final slurry settlement, where the average vacuum pressure inside slurry was derived from Figure 7 as the average vacuum pressure at $h=2 \mathrm{~cm}, 6 \mathrm{~cm}$, and $12 \mathrm{~cm}$. This value was only used for a qualitative analysis. The graph showed that there existed a positive correlation between the average vacuum pressure 


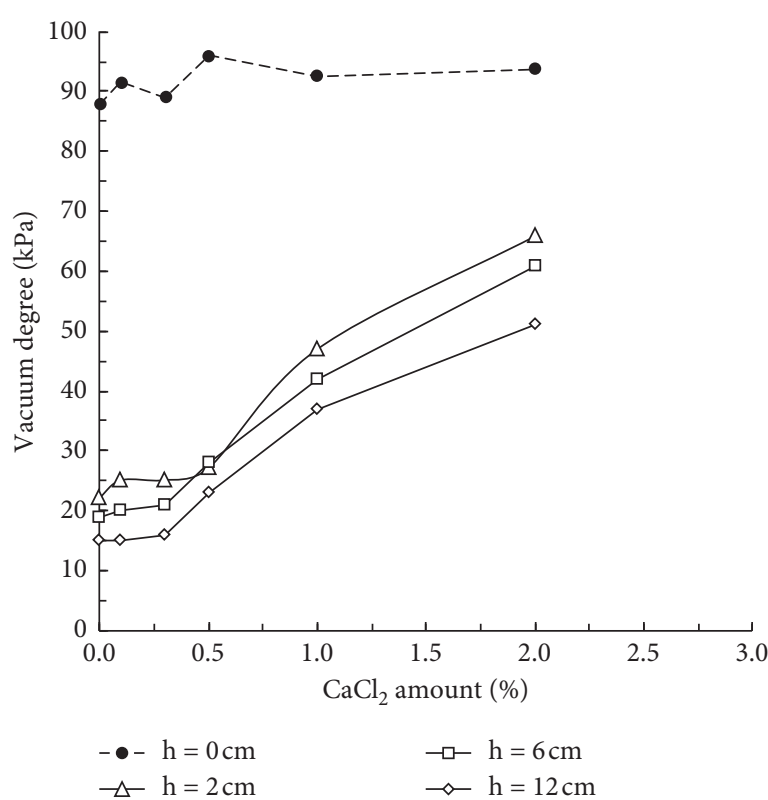

(a)

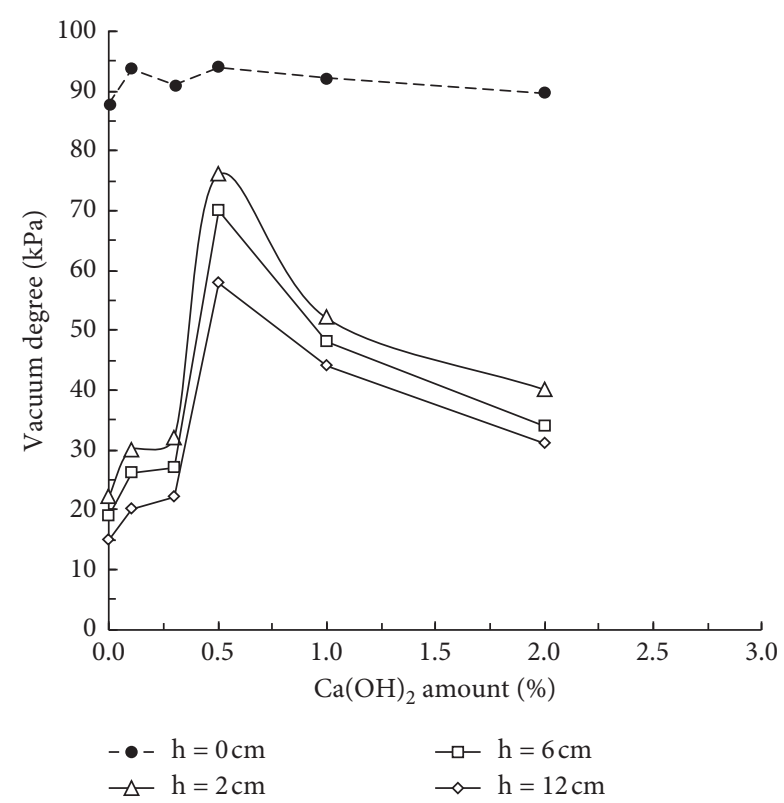

(b)

Figure 7: Variation of stable vacuum degree with flocculants' amount.

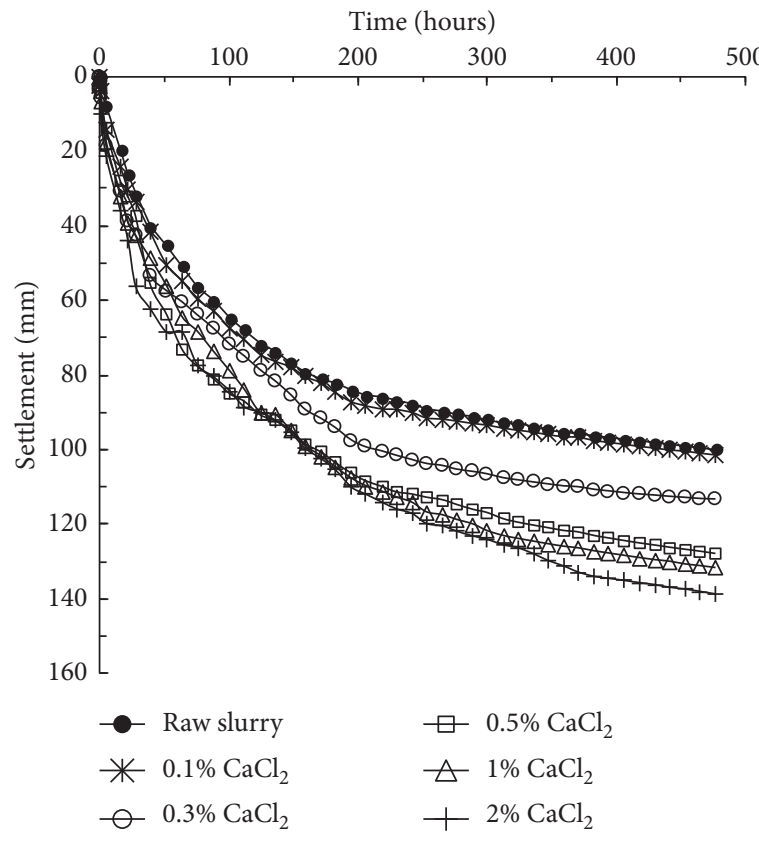

(a)

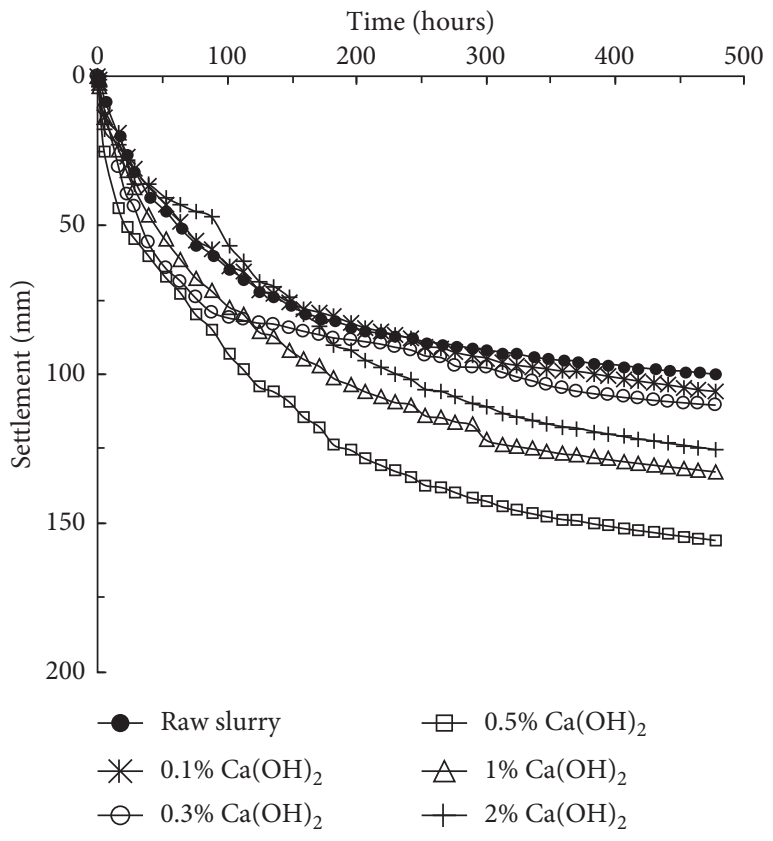

(b)

Figure 8: Settlement versus time.

and the final slurry settlement; that is, the final slurry significantly increased with the average vacuum pressure. Comparison between the settlement value between slurry with $\mathrm{Ca}(\mathrm{OH})_{2}$ and $\mathrm{CaCl}_{2}$ showed that the final settlement was almost the same when the average vacuum pressure was the same. This may suggest that the efficiency of vacuum transmission inside the slurry played a decisive role in the effect of vacuum treatment (i.e., the slurry settlement).
3.4. Extracted Water Amount. Figure 10 depicts the evolution of extracted water amount. Obviously, the variation of extracted water amount with time was similar to that of settlement characteristics because, according to the soil consolidation theory, the soil deformation mainly resulted from the water extracted from soil due to the continuous pressure. The variation of final extracted water amount was also plotted in Figure 9. It can be 


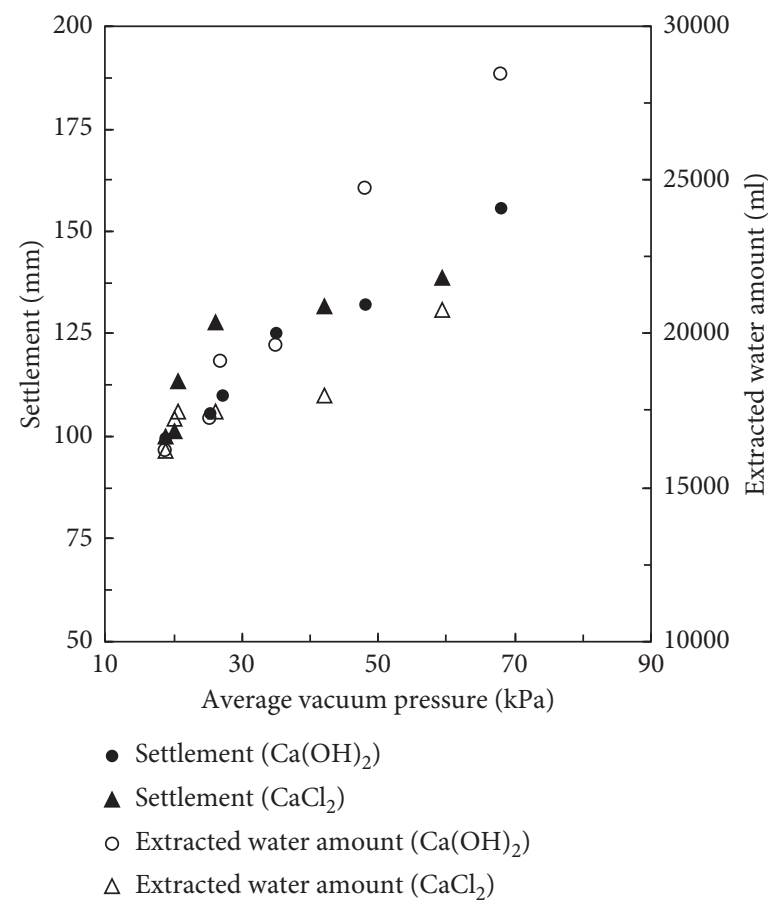

FIGURE 9: Variation of average vacuum pressure with settlement and extracted water amount.

observed that the final extracted water amount increased with the average vacuum pressure, which is consistent with the behaviour of final settlement. These observations also emphasize that the repeatability of these model tests was good in this study. However, it should be pointed out that the difference of extracted water amount between the slurry with $\mathrm{Ca}(\mathrm{OH})_{2}$ and $\mathrm{CaCl}_{2}$ was much larger than the difference in final settlement. This was mainly due to the fact that the water amount was collected by a graduated bottle which measured manually once a few days, leading to some extent of errors on the magnitude of extracted water.

\section{Discussion}

To evaluate the effect of vacuum preloading on the slurry with different flocculants, the water content and undrained shear strength of soil after vacuum preloading was investigated at the distance to $P V D$ of $2 \mathrm{~cm}, 6 \mathrm{~cm}$, and $12 \mathrm{~cm}$, corresponding to the location of vacuum probes. Figure 11 presents the variation of water content and undrained shear strength after treatment with $\mathrm{Ca}(\mathrm{OH})_{2}$ or $\mathrm{CaCl}_{2}$ amount. It is clear that when $\mathrm{Ca}(\mathrm{OH})_{2}$ or $\mathrm{CaCl}_{2}$ was added into the slurry, the water content decreased rapidly at the same distance, resulting in a significant increase in undrained shear strength of slurry after vacuum preloading treatment, in comparison with that of raw slurry. When $\mathrm{CaCl}_{2}$ increased from $0 \%$ to $2 \%$, the reduction of water content of after-treatment soil ranged from $15.7 \%$ to $23.6 \%$; the rise of undrained shear strength of aftertreatment soil ranged from $69.7 \%$ to $84.7 \%$, for soil at $h=2$ to $12 \mathrm{~cm}$. For the slurry treated by $\mathrm{Ca}(\mathrm{OH})_{2}$ with optimal amount of $0.5 \%$, the water content of after-treatment soil decreased by $23.5 \%$ to $27.8 \%$, and the undrained shear strength of after-treatment soil increased by $110 \%$ to $131 \%$. These results imply that the use of $\mathrm{Ca}(\mathrm{OH})_{2}$ and $\mathrm{CaCl}_{2}$ can significantly improve the efficiency of vacuum preloading on slurry, leading to a higher undrained shear strength and a lower water content after-treatment at the same preloading period.

Hence, it is clear that the main purpose of calciumbased flocculants inside slurry was to form larger soil aggregates, accelerating the soil settlement. This will make easier the water extraction from the slurry. Therefore, the settlement rate and water extracting rate at the beginning stage increased significantly when $\mathrm{Ca}(\mathrm{OH})_{2}$ or $\mathrm{CaCl}_{2}$ was used as shown in Figures 8 and 9, respectively. Consequently, the lower energy was consumed due to easier water flow through the favourable soil net-frame structure induced by flocculants $[6,19]$, which was attributable to the higher vacuum transmission efficiency inside slurry, leading to the higher vacuum pressure applied to slurry (higher vacuum degree with flocculants as shown in Figure 7). It is evident that the applied vacuum pressure inside slurry seemed to control the effect of vacuum preloading treatment. Figure 12 shows the relationship between vacuum pressure and water content/undrained shear strength after vacuum preloading treatment. It can be observed that the aftertreatment undrained shear strength of soil increased with the vacuum pressure, while the after-treatment water content of soil showed a decrease trend, irrespective of 


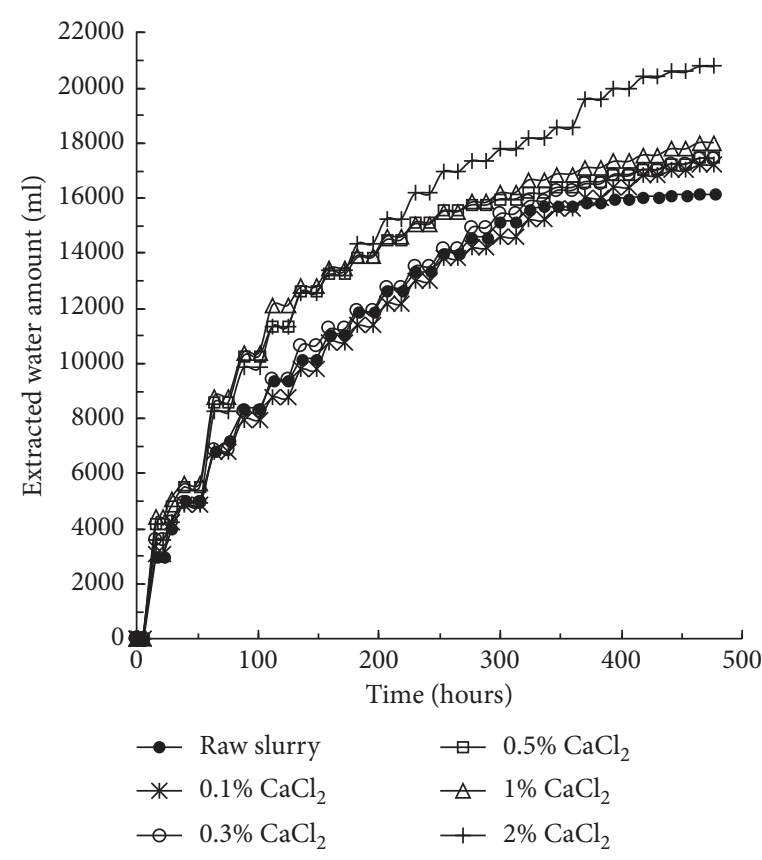

(a)

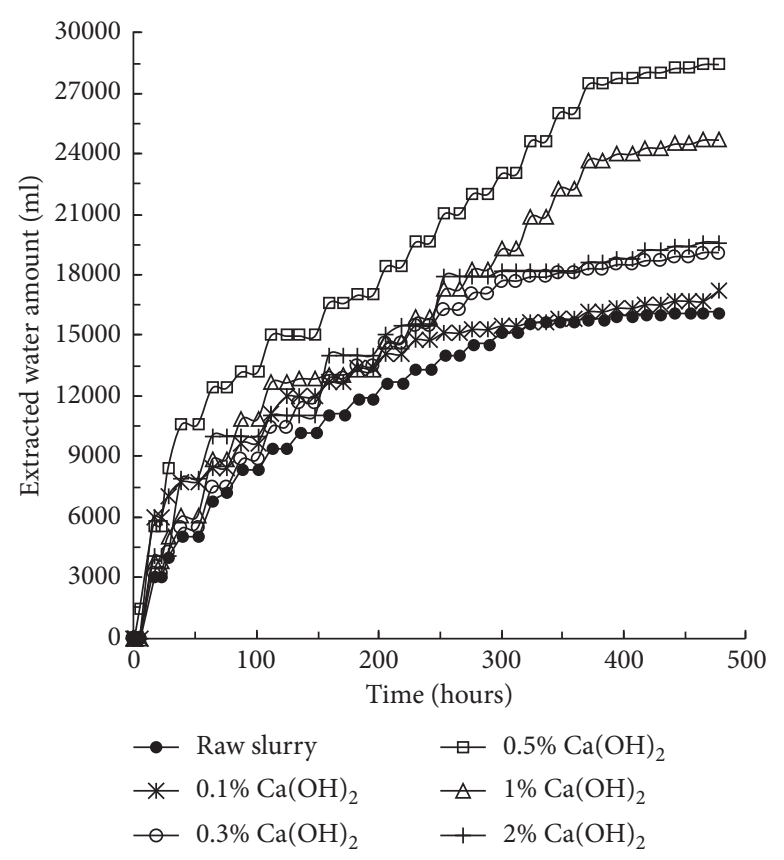

(b)

FIGURE 10: Extracted water content versus time.

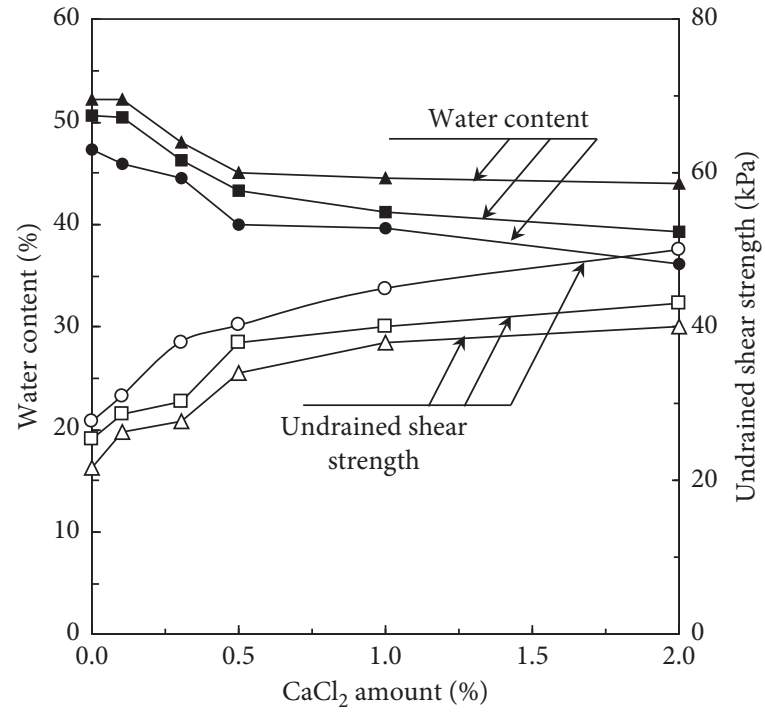

- $\mathrm{O} \mathrm{h}=2 \mathrm{~cm}$

- $\square \mathrm{h}=6 \mathrm{~cm}$

$\Delta \Delta \mathrm{h}=12 \mathrm{~cm}$

(a)

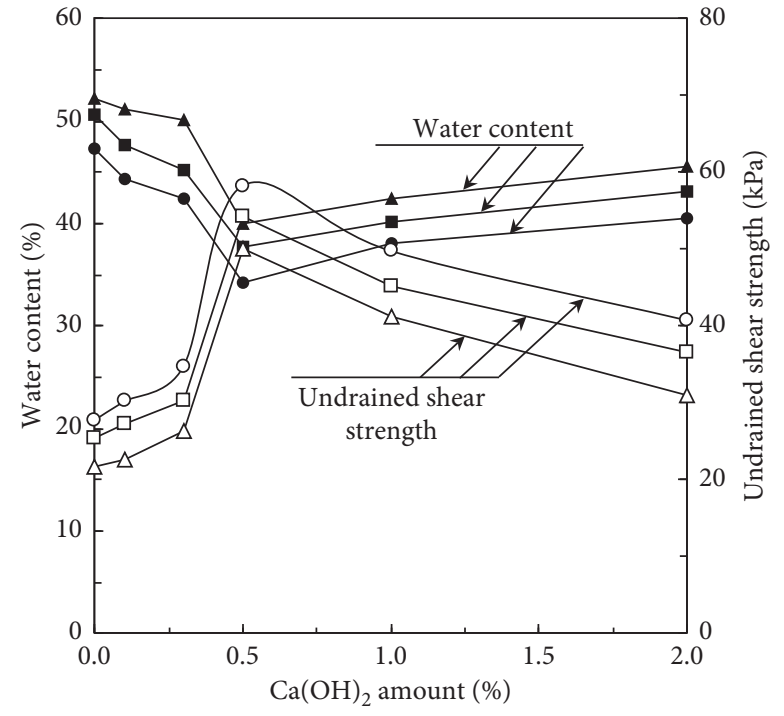

- $\circ \mathrm{h}=2 \mathrm{~cm}$

- $\square \mathrm{h}=6 \mathrm{~cm}$

$\Delta \Delta \mathrm{h}=12 \mathrm{~cm}$

FIGURE 11: Variation of water content and undrained shear strength after vacuum preloading treatment.

$\mathrm{Ca}(\mathrm{OH})_{2}$ or $\mathrm{CaCl}_{2}$ amount. This suggests that the increase of vacuum transmission rate inside slurry due to the calcium-based flocculants was the main reason for the improvement of efficiency of vacuum preloading.

However, the vacuum preloading efficiency did not linearly increase with the amount of calcium-based flocculants as shown in Figure 11(b). In this study, the after-treatment undrained shear strength decreased with $\mathrm{Ca}(\mathrm{OH})_{2}$ amount when it exceeded $0.5 \%$. This means that, for a given initial water content, there was a threshold value of flocculants; when the flocculants' amount was lower than the threshold, the vacuum preloading efficiency increased with flocculants' amount. Once exceeding the threshold, the vacuum preloading efficiency 


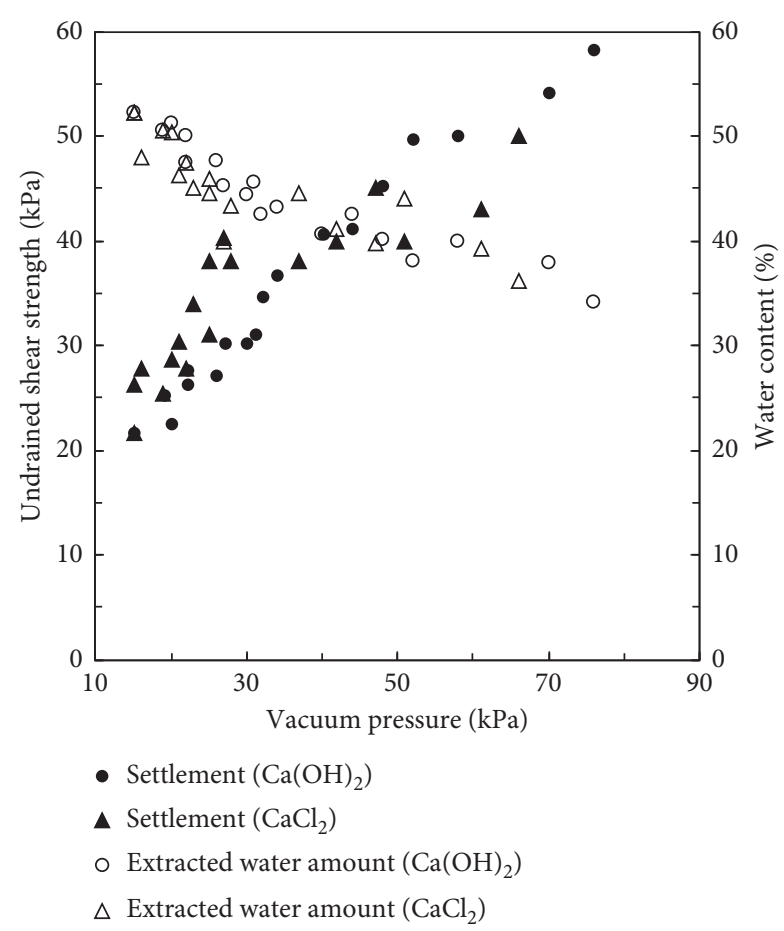

FIGURE 12: Relationship between vacuum pressure and water content/undrained shear strength after vacuum preloading treatment.

decreased with flocculants' amount. When the $\mathrm{Ca}(\mathrm{OH})_{2}$ amount was lower, the larger formation of soil aggregates due to flocculation effect tended to form the net-frame structure, which was beneficial to the water flow [6]. Hence, the vacuum degree inside slurry increased due to the larger vacuum transmission rate with the increase in $\mathrm{Ca}(\mathrm{OH})_{2}$ amount. On the other hand, when the $\mathrm{Ca}(\mathrm{OH})_{2}$ amount exceeded $0.5 \%$, the large soil flocs would tightly enwrap the PVD and reduce the drainage capacity of PVD, which eventually delay the vacuum transmission rate. Consequently, the vacuum pressure decreased with $\mathrm{Ca}(\mathrm{OH})_{2}$ amount in the range higher than $0.5 \%$, leading to the decrease in after-treatment undrained shear strength as shown in Figure 11(b).

In summary, the adequate calcium-based flocculants $\left(\mathrm{Ca}(\mathrm{OH})_{2}\right.$ or $\left.\mathrm{CaCl}_{2}\right)$ were recommended to accelerate the slurry settlement and improve the efficiency of vacuum preloading treatment. Meanwhile, it is still needed to be cautious with the amount of calcium-based flocculants used to avoid the blockage of large soil aggregates on PVD due to the flocculation effect with overdosage of $\mathrm{Ca}(\mathrm{OH})_{2}$ or $\mathrm{CaCl}_{2}$, which may result in the further reduction in after-treatment soil strength in practice.

\section{Conclusions}

This paper proposed a study to use two calcium-based flocculants $\left(\mathrm{Ca}(\mathrm{OH})_{2}\right.$ or $\left.\mathrm{CaCl}_{2}\right)$ as additives improving the efficiency of vacuum preloading in the treatment of slurry. The effect of $\mathrm{Ca}(\mathrm{OH})_{2}$ and $\mathrm{CaCl}_{2}$ on vacuum transmission characteristics, slurry settlement, and extracted water amount was investigated. The efficiency of vacuum preloading in terms of after-treatment undrained shear strength and water content was discussed with respect to the variation of vacuum pressure inside slurry with flocculants' amount. The following conclusions can be drawn from this study:

(1) With the increase in $\mathrm{CaCl}_{2}$ amount up to $2 \%$, the vacuum transmission increased sharply with an increase in vacuum pressure inside the slurry. Meanwhile, the vacuum pressure inside the slurry increased with $\mathrm{Ca}(\mathrm{OH})_{2}$ amount up to $0.5 \%$, followed by a decrease in vacuum pressure with further increase in $\mathrm{Ca}(\mathrm{OH})_{2}$ amount. These behaviour suggests that there was an optimal flocculants' amount to produce the highest vacuum degree inside the slurry

(2) A rapid increase of settlement rate and extracted water amount at the beginning was observed when the two calcium-based flocculants were used. The final slurry settlement and extracted water content showed a positive correlation with the average vacuum degree inside the slurry.

(3) An increase in after-treatment undrained shear strength and a decrease in after-treatment water content of soil with the vacuum pressure were observed irrespective of $\mathrm{Ca}(\mathrm{OH})_{2}$ or $\mathrm{CaCl}_{2}$ amount. This suggests that the increase of vacuum transmission rate inside the slurry due to the calciumbased flocculants was the main reason for the improvement of the efficiency of vacuum preloading.

(4) The acceleration of soil settlement due to flocculation effect with $\mathrm{Ca}(\mathrm{OH})_{2}$ and $\mathrm{CaCl}_{2}$ was the main reason for the improvement of vacuum preloading efficiency. The increase in soil flocs tended to refine the net-frame structure and water flow path, which positively contributed to the vacuum preloading treatment efficiency. Otherwise, overdosage of flocculants may result in the blockage of blockage of large soil aggregates on PVD, which reduce the vacuum transmission rate inside the slurry, leading to the decrease in the after-treatment soil strength.

\section{Data Availability}

The data used to support the findings of this study are included within the article.

\section{Conflicts of Interest}

The authors declare that they have no conflicts of interest regarding the publication of this paper.

\section{Acknowledgments}

The authors wish to acknowledge the support of the China Postdoctoral Science Foundation (Grant nos. 2016M600396 and 2017T100355). Partial financial support from the Fundamental Research Funds for the Central Universities of China (Grant no. B200204001), the Fundamental Research 
Funds for the Chinese Academy of Geological Science (no. JKY201909), and Jiangsu Natural Resources Science and Technology Fund (KJXM2019025) was also acknowledged.

\section{References}

[1] X. Bian, Z.-F. Wang, G.-Q. Ding, and Y.-P. Cao, "Compressibility of cemented dredged clay at high water content with super-absorbent polymer," Engineering Geology, vol. 208, pp. 198-205, 2016.

[2] X. Bian, Y. P. Cao, Z. F. Wang, and G. Q. Ding, G. H. Lei, Effect of super-absorbent polymer on the undrained shear behavior of cemented dredged clay with high water content," ASCE Journal of Materials in Civil Engineering, vol. 29, no. 7, Article ID 04017023, 2017.

[3] X. Bian, L. Zeng, Y. Deng, and X. Li, "The role of superabsorbent polymer on strength and microstructure development in cemented dredged clay with high water content," Polymers, vol. 10, no. 10, p. 1069, 2018.

[4] L.-L. Zeng, Z.-S. Hong, and Y.-J. Cui, "On the volumetric strain-time curve patterns of dredged clays during primary consolidation," Géotechnique, vol. 65, no. 12, pp. 1023-1028. 2015, In press.

[5] F. L. Min, X. Y. Wang, M. D. Li, Y. X. Ni, E. Al-qadhi, and J. F. Zhang, "Preparation of high porosity and high strength ceramisites from municipal sludge using starch and $\mathrm{CaCO}_{3}$ as a combined pore-forming agent," Journal of Materials in Civil Engineering, 2020.

[6] J. Wang, G. Huang, H. Fu et al., "preloading combined with multiple-flocculant treatment for dredged fill improvement," Engineering Geology, vol. 259, Article ID 105194, 2019.

[7] M. W. Bo, A. Arulrajah, and H. Nikraz, "Preloading and prefabricated vertical drains design for foreshore land reclamation projects: a case study," Proceedings of the Institution of Civil Engineers - Ground Improvement, vol. 11, no. 2, pp. 67-76, 2007.

[8] Y. Cai, Z. Xie, J. Wang, P. Wang, and X. Geng, "Reply to the discussion by mesri and kane on new approach of vacuum preloading with booster prefabricated vertical drains (PVDs) to improve deep marine clay strata," Canadian Geotechnical Journal, vol. 56, no. 12, p. 2017, 2019.

[9] J. Chai, Z. Hong, and S. Shen, "Vacuum-drain consolidation induced pressure distribution and ground deformation," Geotextiles and Geomembranes, vol. 28, no. 6, pp. 525-535, 2010.

[10] J. Chu, M. W. Bo, and A. Arulrajah, "Soil improvement works for an offshore land reclamation," Proceedings of the Institution of Civil Engineers - Geotechnical Engineering, vol. 162, no. 1, pp. 21-32, 2009.

[11] B. Indraratna, C. Rujikiatkamjorn, A. S. Balasubramaniam, and G. McIntosh, "Soft ground improvement via vertical drains and vacuum assisted preloading," Geotextiles and Geomembranes, vol. 30, pp. 16-23, 2012.

[12] D. Basu and M. R. Madhav, "Effect of prefabricated vertical drain clogging on the rate of consolidation: a numerical study," Geosynthetics International, vol. 7, no. 3, pp. 189-215, 2000.

[13] Y. Cao, J. Xu, X. Bian, and G. Xu, "Effect of clogging on large strain consolidation with prefabricated vertical drains by vacuum pressure," KSCE Journal of Civil Engineering, vol. 23, no. 10, pp. 4190-4200, 2019.

[14] J. Chu, M. Bo, and V. Choa, "Improvement of ultra-soft soil using prefabricated vertical drains," Geotextiles and Geomembranes, vol. 24, no. 6, pp. 339-348, 2006.
[15] J. Wang, Y. Cai, J. Ma et al., "Improved vacuum preloading method for consolidation of dredged clay-slurry fill," Journal of Geotechnical and Geoenvironmental Engineering, vol. 142, no. 11, Article ID 06016012, 2016.

[16] Y. Zhuang, X. Y. Cui, S. Zhang, G. L. Dai, and X. L. Zhao, “The load transfer mechanism in reinforced piled embankment under cyclic loading and unloading," European Journal of Environmental and Civil Engineering, 2020, In press.

[17] J. Wang, J. Ni, Y. Cai, H. Fu, and P. Wang, "Combination of vacuum preloading and lime treatment for improvement of dredged fill," Engineering Geology, vol. 227, pp. 149-158, 2017.

[18] D. Ni, W. Xu, and R. Tjuar, "Improvements of marine clay slurries using chemical-physical combined method (CPCM)," Journal of Rock Mechanics and Geotechnical Engineering, vol. 7, no. 2, pp. 220-225, 2015.

[19] J. Mallela, H. Von Quintus, P. E. Kelly, and L. Smith, Consideration of Lime-Stabilized Layers in Mechanistic-Empirical Pavement Design, The National Lime Association location, Arlington, VA, USA, 2017.

[20] T.-H. Chang and H.-W. Chang, "Improvement of liquefaction resistance of reclaimed sand in water-an experimental study," Journal of GeoEngineering, vol. 5, no. 2, pp. 39-49, 2010.

[21] Y. Gao, L. Hang, J. He, and J. Chu, "Mechanical behaviour of biocemented sands at various treatment levels and relative densities," Acta Geotechnica, vol. 14, no. 3, pp. 697-707, 2019.

[22] J. He, Y. F. Gao, Z. Gu, J. Chu, and L. Wang, "Characterization of crude bacterial urease for $\mathrm{CaCO}_{3}$ precipitation and cementation of silty sand," Journal of Materials in Civil Engineering, vol. 32, no. 5, Article ID 04020071, 2020.

[23] ASTM D2487, Standard Practice for Classification of Soils for Engineering Purposes (Unified Soil Classification System), ASTM International, West Conshohocken, PA, USA, 2011.

[24] X. Bian, Y.-J. Cui, and X.-Z. Li, "Voids effect on the swelling behaviour of compacted bentonite," Géotechnique, vol. 69, no. 7, pp. 593-605, 2019a.

[25] X. Bian, Y.-J. Cui, L.-L. Zeng, and X.-Z. Li, "Swelling behavior of compacted bentonite with the presence of rock fracture," Engineering Geology, vol. 254, pp. 25-33, 2019b.

[26] X. Bian, Y.-J. Cui, L.-L. Zeng, and X.-Z. Li, "State of compacted bentonite inside a fractured granite cylinder after infiltration," Applied Clay Science, vol. 186, Article ID 105438, 2020.

[27] C. Liu, G. Xu, and B. Xu, "Field study on the vacuum preloading of dredged slurry with wheat straw drainage," KSCE Journal of Civil Engineering, vol. 22, no. 11, pp. 4327-4333, 2018.

[28] G.-Z. Xu, J. Yin, X.-S. Feng, and F. Ji, “An improved method for dewatering sewage sludge using intermittent vacuum loading with wheat straw as vertical drains," KSCE Journal of Civil Engineering, vol. 24, no. 7, pp. 2017-2025, 2020. 